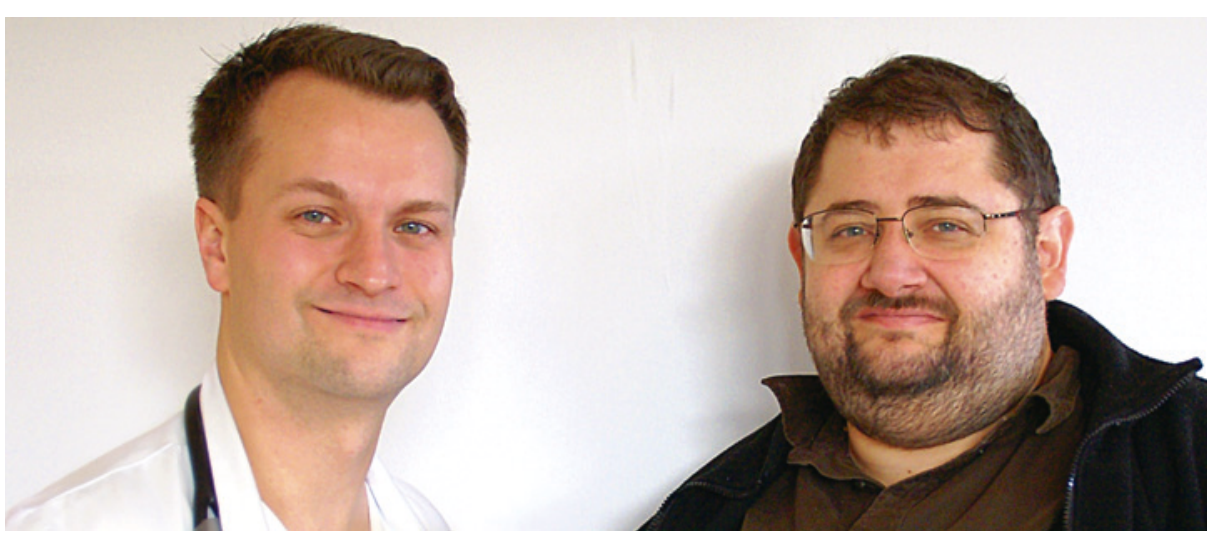

Lars Erik Laugsand og Imre Janszky. Foto Ida Sortland Knudsen, Norges teknisk-naturvitenskapelige universitet

\title{
Skiftarbeid øker risikoen for hjerte- og karsykdom
}

Skiftarbeid er assosiert med økt risiko for hjerteinfarkt, iskemisk hjerneslag og koronare hendelser. Det viser en ny metaanalyse.

Tidligere studier indikerer at dårlig søvn og søvnlidelser bidrar til utvikling av hjerteog karsykdom. Det er velkjent at skiftarbeid påvirker cirkadiane rytmer og søvnkvalitet. I tillegg har skiftarbeidere oftere dyslipidemi, hypertensjon og diabetes mellitus. Likevel har studier om sammenheng mellom skiftarbeid og hjerte- og karsykdom vist motstridende resultater.

I en ny studie gjennomgikk forskerne systematisk alle observasjonsstudier som rapporterte et mål for risiko for assosiasjonen mellom skiftarbeid og hjerteinfarkt, iskemisk hjerneslag eller koronar hendelse. Ved systematisk litteratursøk ble det identifisert 34 studier som til sammen omfattet over to millioner personer. Skiftarbeid ble definert som ettermiddagsskift, irregulære eller uspesifiserte skift, nattskift eller roterende skift. Kontrollgruppe var dagarbeidere eller den generelle befolkningen. Det ble tatt hensyn til forskjeller i studiedesign og kvalitet for å minimalisere skjevheter (bias). I studiene forekom det til sammen 6598 hjerteinfarkter, 17359 koronare hendelser og 1854 hjerneslag.

Metaanalysen viste at skiftarbeid var assosiert med økt risiko for hjerteinfarkt (RR 1,23; $95 \%$ KI 1,15-1,31), iskemisk hjerneslag (RR 1,05; 1,01-1,09) og koronar hendelse (RR 1,24; 1,10-1,39). Nattarbeid var sterkest assosiert med risiko for koronar hendelse (RR 1,41; 1,13-1,76). Skiftarbeid var ikke assosiert hjerte- og kardødelighet eller totaldødelighet.

Helseundersøkelsen i Nord-Trøndelag (HUNT2), der mer enn 65000 personer deltok, var inkludert i metaanalysen. I HUNT2 var skiftarbeid assosiert med moderat økt risiko for hjerteinfarkt (RR 1,37; 1,14-1,66).
- Estimatene var justert for alder, kjønn, etablerte kardiovaskulære risikofaktorer og sosioøkonomisk status. Ugunstig livsstil kunne derfor ikke fullstendig forklare assosiasjonen mellom skiftarbeid og kardiovaskulær sykdom, sier postdoktor Lars Erik Laugsand, som var en av de norske forfatterne bak metaanalysen. - Til tross for at sammenhengen er moderat, er andelen skiftarbeidere $\mathrm{i}$ befolkningen såpass høy at den overordnede risiko er høy. Metaanalysen taler derfor for at skiftarbeidere bør være særlig opptatt av livsstilsendringer eller forebyggende behandling for å redusere risikoen for hjerte- og karsykdom. Nye studier bør identifisere sårbare undergrupper av skiftarbeidere og langtidseffekter på risikoen for hjerte- og karsykdom ved å endre organiseringen av skiftarbeidet, sier Laugsand.

\section{Forskergruppen}

Forskergruppen besto hovedsakelig av kanadiske forskere fra Western University i Ontario. Imre Janszky og Lars Erik Laugsand sto for det norske bidraget. Janszky og Laugsand arbeider ved Institutt for samfunnsmedisin, Norges teknisk-naturvitenskapelige universitet, og har særlig interesse for epidemiologi og folkehelse. De ble invitert til å delta i gruppen pga. tidligere forskning om søvnløshet og risiko for hjerteinfarkt og bidro bl.a. med tall fra HUNT-undersøkelsen.

\section{Erlend Hem}

erlend.hem@medisin.uio.no

Tidsskriftet

\section{Litteratur}

Litteratur
1. Vyas MV, Garg AX, lansavichus AV et al. Shift work and vascular events: systematic review and metaanalysis. BMJ 2012; 345: e4800.
Ordforklaringer

Skiftarbeid: Ethvert arbeid som ikke gjøres på dagtid, dvs. fra kl 9 til kl 17. Arbeidet gjennomføres planmessig på ulike tider av døgnet.

Cirkadiane rytmer: Betegnelsen på de naturlige døgnsvingninger i levende celler.

Metaanalyse: En analyse av tidligere empiriske undersøkelser av et fenomen.

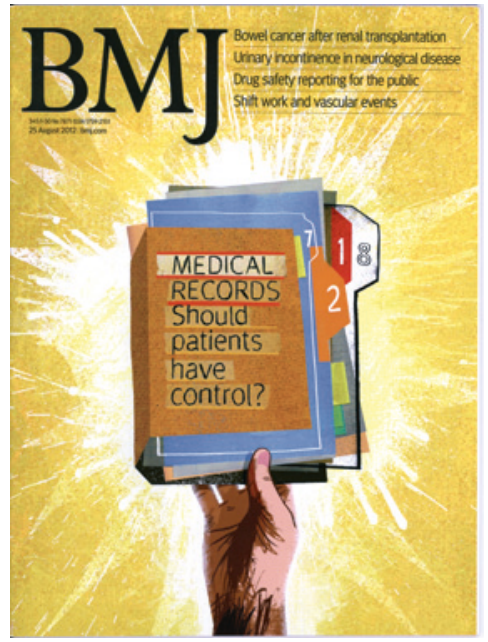

Artikkelen ble e-publisert 26.7. 2012 i BMJ (www.bmj.com), som regnes som en av de «fem store» innen medisinsk publisering, ved siden av New England Journal of Medicine, JAMA, Annals of Internal Medicine og The Lancet. 